\title{
Study on the suspended particulate matter of a Mediterranean artificial lake (Sos Canales Lake) using Stable Isotope Analysis of carbon and nitrogen
}

\author{
Amedeo Fadda ${ }^{1 *}$, Marina Manca ${ }^{2}$, Federica Camin $^{3}$, Luca Ziller ${ }^{3}$, Paola Buscarino ${ }^{4}$, \\ Mariantonietta Mariani ${ }^{1}$, Bachisio Mario Padedda ${ }^{1}$, Nicola Sechi ${ }^{1}$, Tomasa Virdis ${ }^{4}$ and \\ Antonella Lugliè ${ }^{1}$ \\ 1 Dipartimento di Scienze della Natura e del Territorio, University of Sassari, via Piandanna 4, Sassari, Italy \\ 2 CNR Institute of Ecosystem Study (CNR-ISE), Largo Tonolli 50, Verbania, Italy \\ 3 IASMA Fondazione Edmund Mach, San Michele all'Adige, TN, Italy \\ 4 Ente Acque della Sardegna, via Mameli 88, Cagliari, Italy
}

Received 30 July 2016; Accepted 4 November 2016

\begin{abstract}
Stable isotope analysis of carbon $(\mathrm{C})$ and nitrogen $(\mathrm{N})$ was used to study the nature and origin of the suspended particulate matter (SPM) in a small Mediterranean reservoir, Lake Sos Canales (SC). The $\delta^{13} \mathrm{C}$ and $\delta^{15} \mathrm{~N}$ isotopic ratios, physical-chemical parameters, nutrients and phytoplankton were analyzed $c a$. monthly over a hydrological year on the vertical profile at two stations (lacustrine and riverine). SPM quantity and composition were related to the hydrological annual dynamic. In Mediterranean reservoirs, water-level fluctuation is one of the most important stressors, largely dependent on the strong seasonality of climate and water exploitation for human uses. Mediterranean reservoirs show different phases during a hydrological year, alternating empty and low water level (summer-autumn), re-filling (winter-spring) and high water (spring-summer) phases. Isotopic ratios of $\mathrm{C}$ and $\mathrm{N}$ were similar on the vertical profile and at the two stations during the low water phase, but differed during the re-filling and high water phases. Significant correlations were found between $\delta^{15} \mathrm{~N}$ and water level, and between $\delta^{13} \mathrm{C}$ and temperature in the surface layer at the lacustrine station. An unusual $\delta^{13} \mathrm{C}$ distribution along the water column during the re-filling phase was interpreted on the basis of phytoplankton species composition, mainly due by Gymnodinium uberrimum.
\end{abstract}

Key words: water-level fluctuation / stable isotope analysis / LTER / dinoflagellate / suspended particulate matter

\section{Introduction}

Since the last century, in the Mediterranean region, increasing water demand for human need has been met often by damming rivers or streams, and constructing artificial lakes.

One of the most relevant features of Mediterranean artificial lakes is their large water-level fluctuation (WLF), caused by the strong seasonality of both the climate and water uses (Naselli-Flores, 2003; Naselli-Flores and Barone, 2005). In fact, Mediterranean artificial lakes show different phases during a hydrological year, alternating empty and low water-level phase, during the drought season (summer-autumn), re-filling (winter-spring) and

\footnotetext{
*Corresponding author: amedeofadda@gmail.com
}

high water (spring-beginning summer) phases, during the wet season. Consequently, the littoral zones of Mediterranean artificial lakes are relatively wide and only periodically submerged, especially when the lakes are used for human water exploitation such as for agriculture and hydropower production. Thus, phytoplankton is the most important primary producer at the base of the aquatic food web.

Phytoplankton is one of the main components of the suspended particulate matter (SPM) in aquatic ecosystems. SPM composition can be originated by internal production processes, constituted mainly by phytoplankton, bacteria and zooplankton, as well as by external sources, composed mainly of material transported by the river. Stable Isotope Analysis (SIA) of carbon (C) and nitrogen $(\mathrm{N})$ is a useful tool for studying the origin of 
SPM. SIA is a relatively recent method for tracing nutrient fluxes within ecosystems, and studying food webs, trophic relationships, and pathways of energy flow, in particular in aquatic environments (Grey, 2006; Visconti et al., 2013a; Fadda et al., 2014, and references therein). At a general level, $\mathrm{C}$ isotope composition $\left({ }^{13} \mathrm{C} /{ }^{12} \mathrm{C} ; \delta^{13} \mathrm{C}\right)$ changes little along trophic transfer, whereas $\mathrm{N}\left({ }^{15} \mathrm{~N} /{ }^{14} \mathrm{~N} ; \delta^{15} \mathrm{~N}\right)$ tends to be enriched (referred to as the heavy isotope; Sulzman, 2008). Consequently, C isotope composition can be used for determining the food source of various organisms, whereas $\mathrm{N}$ composition allows estimates of their relative position in the trophic chain (Vander Zanden and Rasmussen, 1999; Visconti et al., 2013b). The $\delta^{13} \mathrm{C}$ of SPM has provided important insights into sources of organic matter, primary productivity and $\mathrm{CO}_{2}$ concentration in surface waters (Lehman et al., 2004), while $\delta^{15} \mathrm{~N}$ has been used to understand various $\mathrm{N}$ cycling processes (Teranes and Bernasconi, 1999; Lehman et al., 2004).

In lacustrine systems, $\delta^{13} \mathrm{C}$ and $\delta^{15} \mathrm{~N}$ ratios vary over time (Zohary et al., 1994; Lehman et al., 2004); this variability is related to external loadings, phytoplankton species composition, primary productivity, as well as sources and concentrations of dissolved inorganic $\mathrm{C}$ and N (Grey and Jones, 2001; Caroni et al., 2012). Anyway, most of the knowledge on lacustrine $\delta^{13} \mathrm{C}$ and $\delta^{15} \mathrm{~N}$ ratios derives from studies on natural lakes, whereas data on artificial lakes are rare.

On a hydrological year, in small artificial lakes (sensu Straškraba and Tundisi, 1999), external inputs from watersheds (i.e., matter of terrestrial origin) are relevant during the wet season, while internal recycling processes support biological communities during the drought season (Zohary and Ostrovsky, 2011). Because of the marked differences between isotopic ratios of terrestrial and aquatic origin matter (Finlay and Kendall, 2008), a low isotopic $\mathrm{C}$ ratio (i.e., terrestrial ratio) is expected during the wet season (i.e., filling phase), whereas a relative increase in the isotopic ratio (i.e., aquatic ratio) is expected in the dry months, when input from watershed is minimal. In addition, hydrological stressors, such as WLF and the relative morphometric characteristics of the lake, can affect the composition of SPM and, consequently, $\delta^{13} \mathrm{C}$ and $\delta^{15} \mathrm{~N}$ ratios.

Determination of SPM origin is critical for understanding the relative importance of the autochthonous primary trophic level with respect to allochtonous inputs to the lacustrine food web. In the management practices of artificial lakes, know the SPM origin provides a basic information for a top-down control (e.g., grazing) and can be a useful strategy for controlling phytoplankton growth (Jeppesen et al., 1999). Artificial Mediterranean lakes are of strategic importance to the socio-economical development. They require site-specific management plans, which should take into account the effects of strong stresses of both natural (e.g., climate of the region) and anthropogenic origin (e.g., eutrophication, water management) and adopt management tools that lead to the better utilization of water resources (Tundisi and MatzumuraTundisi, 2003).

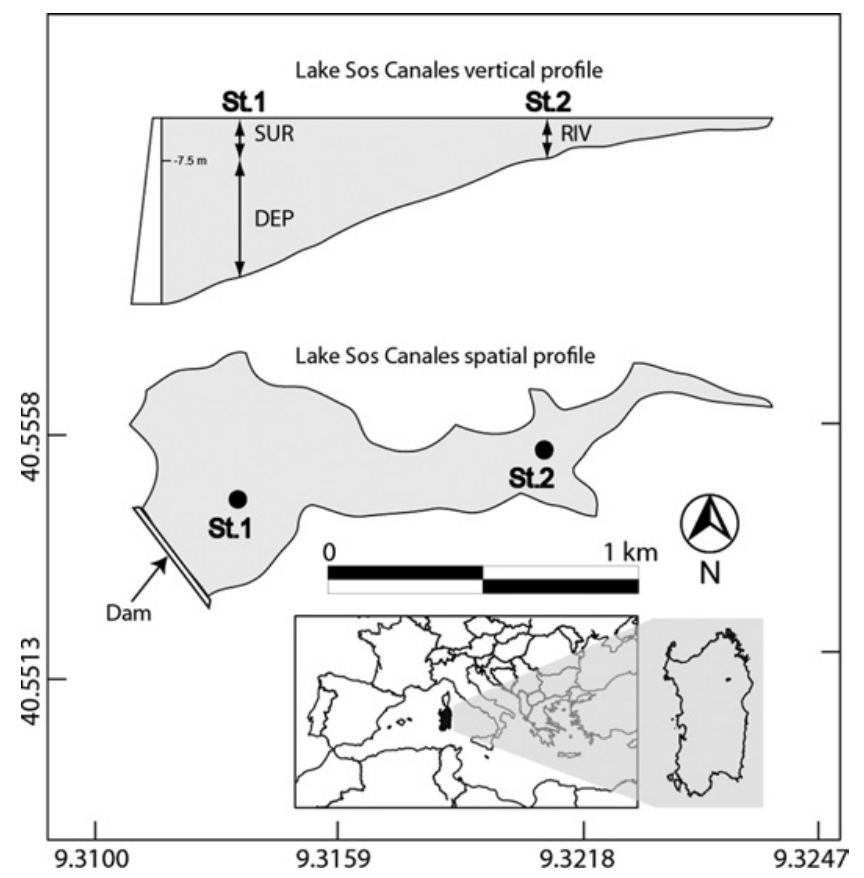

Fig. 1. SC Lake and sampling station locations (St. 1: lacustrine station; St. 2: riverine station).

The aim of this study was to evaluate the origin and annual dynamic of SPM using SIA of $\mathrm{C}$ and $\mathrm{N}$ in a Mediterranean artificial lake. The objective was to give a contribution to the poorly known isotope ratios of SPM in artificial lakes in the Mediterranean area.

\section{Materials and methods}

\section{Study area}

Sos Canales Lake (SC) was built in 1956 by damming the upper stream of River Tirso, the most important river in Sardinia (Italy; Fig. 1), which is the second largest island of the Mediterranean Sea. SC is located in a small, relatively pristine watershed, surrounded by cork-oaks woods. The water catchment is small and granitic (Fig. 1). Though difficult to quantify, there are a small number of anthropogenic activities in the watershed, mainly associated with cork production and breeding. Despite the low impact of human activities, and a relatively low (theoretical) phosphorus load (Sechi and Lugliè, 1992), SC is classified as meso-eutrophic according to OECD criterions (Sechi and Lugliè, 1992; Lugliè et al., 1996; Marchetto et al., 2009). SC belongs to the Italian Network of Long Term Ecological Research (LTER-Italy; www.lteritalia.it). Long-term studies have shown that the phytoplankton, which is the main primary producer within SC, is co-dominated by Cyanobacteria, Dinophyceae, Chlorophyceae and Bacillariophyceae (Sechi and Lugliè, 1996). Fadda et al. (2011) found that SC has the richest and most diverse zooplankton communities among the 15 Sardinian artificial lakes studied. 
SC provides drinking water supply for a resident population of 15000; because of human use, the outflow of the lake is reasonably constant throughout the year, never exceeding $265 \mathrm{~m}^{3}$. month $^{-1}$. A mobile device for selecting water of high quality was installed in 2006 to reduce the costs of drinking water treatment. Water quality is monitored by Remote System Monitoring in Real Time and is managed by the Ente Acque della Sardegna (ENAS), the regional manager of dams and lakes. The system allows data to be obtained on a number of basic variables (temperature, $\mathrm{pH}$, conductivity, dissolved oxygen and fluorimetric chlorophyll a) along a vertical profile throughout the water column.

\section{SPM and SIA}

\section{Sampling}

SPM $(1.2=\mu \mathrm{m} \leq 76)$ samples were collected $c a$. monthly from October 2010 to September 2011 at two stations (Fig. 1). The two stations were chosen as representative of the lacustrine and riverine areas inside the lake: St. 1 was close to the dam at maximum lake depth $(40 \mathrm{~m})$, and St. 2 near to the river inflow, where water depth ranged between 8 and $10 \mathrm{~m}$. The sampling time was restricted to early afternoon (between 13:00 and 14:00 h pm).

Two integrated water samples were obtained on each date at St. 1: one from the layer between the surface and $7.5 \mathrm{~m}$ depth (SUR), and the other from the layer below $10 \mathrm{~m}$ depth (DEP). Samples were collected using a Niskin bottle $(5 \mathrm{~L})$ from depth intervals of $0,1,2.5,5$ and $7.5 \mathrm{~m}$ (SUR) and 10, 15, 20 and $30 \mathrm{~m}$, water depth permitting (always more than $2 \mathrm{~m}$ from the bottom) (DEP).

On the same sampling dates, $0-7.5 \mathrm{~m}$ depth-integrated water samples were collected from the riverine area (St. 2). These samples were collected using a Niskin bottle $(5 \mathrm{~L})$ at depth intervals of $0,1,2.5,5,7.5$ (depth permitting).

To evaluate terrestrial isotopic ratio, earthworms were collected from the lake catchment within each season to assess the effects of the surrounding soil, and benthic oligochaetes were collected at St. 1 (34 m depth), using an Ekman grab in February 2011 to assess the effects of the bottom sediments.

\section{Analysis}

Approximately $1 \mathrm{~L}$ of integrate water samples (obtained mixing $1 \mathrm{~L}$ of each depth samples) were pre-filtered on a $76 \mu \mathrm{m}$ sieve to remove zooplankton and large detritus material, and then filtered on WATMAN GF/C glass-fiber filters ( $4.5 \mathrm{~cm}$ diameter, $1.2 \mu \mathrm{m}$ pore size) and oven dried at $60^{\circ} \mathrm{C}$ for $24 \mathrm{~h}$. The dry-weight of SPM $\left(\mu \mathrm{g} . \mathrm{L}^{-1}\right)$ was evaluated by calculating the net weight between the preweighted empty and full filters, and compensating for the water liter that had been filtered. Filtered portions were transferred into tin capsules $\left(6 \times 4 \mathrm{~mm}^{2}\right)$ for $\delta^{13} \mathrm{C}$ and $\delta^{15} \mathrm{~N}$ SIA.
Earthworms and oligochaetes were stored in clean water for $24 \mathrm{~h}$ for the gut cleaning, and oven dried at $60{ }^{\circ} \mathrm{C}$ for $24 \mathrm{~h}$. Dried samples were powdered and $1 \mathrm{mg}$ was weighted and put into tin capsules $\left(6 \times 4 \mathrm{~mm}^{2}\right)$ for SIA.

Two replicate of each samples were analyzed by Continuous Flow-Isotope Ratio Mass Spectrometer (CF-IRMS; Delta plus XP ThermoFinnigann, Bremen, Germany) at the Istituto Agrario San Michele all'Adige (I.A.S.M.A, Trento, Italy), after total combustion $(\approx 0.5 \mathrm{mg}$ ) in elemental analyzer (EA Flash 1112 ThermoFinnigan) (Camin et al., 2007). Values were expressed in $\delta \%$ against international standards (ViennaPee Dee Belemnite for $\delta^{13} \mathrm{C}$, air for $\delta^{15} \mathrm{~N}$ ) and calculated against acetanilide ratio, which was calibrated against international reference materials (MRI-ET-ISO 64, MRI-ET-ISO 63; Camin et al., 2007). Measurement error was $<0.30 \%$ for $\delta^{13} \mathrm{C}$ and $\delta^{15} \mathrm{~N}$.

\section{Environmental variables, nutrients and phytoplankton}

\section{Sampling}

Sampling was conducted $c a$. monthly at the station in the lacustrine zone (St. 1), at the same dates used for collection of the SPM samples, for chemical-physical, nutrients and phytoplankton analyses. Samples for the chemical-physical variables and nutrients were collected using a Niskin bottle on a vertical profile at fixed depth intervals $(0,1,2.5,5,7.5,10,15 \mathrm{~m}$ and below at intervals of $10 \mathrm{~m}$, always more than $2 \mathrm{~m}$ from the bottom). Sampling for phytoplankton analysis was undertaken at the station in the lacustrine zone (St. 1) as well as at the riverine station (St. 2). Phytoplankton samples $(100 \mathrm{~mL})$ were collected from the first six depth intervals $(0,1,2.5,5,7.5,10 \mathrm{~m})$ and immediately fixed in the field with Lugol's solution.

\section{Measurements, analyses, calculations and statistical data analysis}

Secchi disk transparency (SD) was measured trough a $\mathrm{SD}$ while temperature $(T), \mathrm{pH}$, conductivity (Cond) and dissolved oxygen (DO) were measured in situ by a multiparametric probe (multiprobe Hydrolab DS5). Replicate samples were used for laboratory validation of the values registered in the field for $\mathrm{pH}$ (Orion Research Model 960) and conductivity (Mod Analytical Control 120).

Water samples were preserved in cold and dark conditions for laboratory analysis of alkalinity, ammonium $\left(\mathrm{N}-\mathrm{NH}_{4}\right)$ (Fresenius et al., 1988), nitrite $\left(\mathrm{N}-\mathrm{NO}_{2}\right)$, nitrate $\left(\mathrm{N}-\mathrm{NO}_{3}\right)$, total nitrogen $(\mathrm{TN})$, reactive $(\mathrm{RP})$ and total phosphorus (TP), according to Strickland and Parsons (1972), and chlorophyll $a$ (Chl $a$ ) according to Goltermann et al. (1978). Dissolved inorganic nitrogen (DIN) was calculated by summing the ammonia, nitrate and nitrite concentrations. Organic nitrogen was calculated from the difference between TN and DIN concentrations. The environmental and nutrient data were averaged for SUR and DEP. 


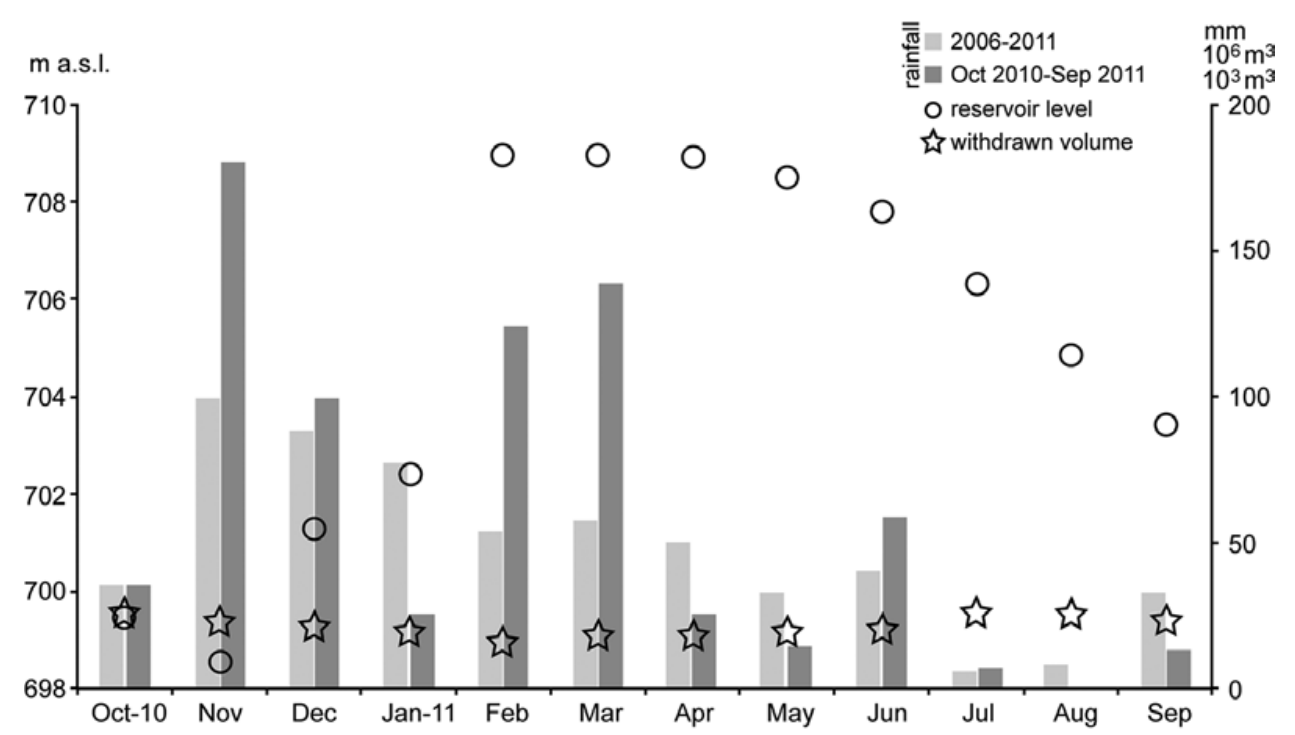

Fig. 2. Lake SC seasonal water level, lacustrine volume, withdraw and rainfall.

Phytoplankton was analyzed using Utermhöl's technique (1958). Cell density was evaluated by taking subsamples of 5-10 $\mathrm{mL}$ from the fixed samples, and using an inverted microscope (Zeiss, Axiovert 10) at $200 \times$ and $400 \times$ magnification in an adequate number of fields. Species were determined on alive and fixed samples according to Huber-Pestalozzi (1938, 1941, 1942, 1955, 1961, 1968, 1982, 1983); Bourrelly (1966-1981); Hustedt (1985); Krammer and Lange-Bertalot (1986-1991); Komárek and Anagnostidis (1999, 2005); Suda et al. (2002); Komárek and Zapomělová (2007, 2008). Biovolume was calculated by multiplying the cell density of each taxon by the mean unitary cell biovolume of the same taxon, which was obtained by geometrical approximation after measurement of at least 30 specimens according to Sun and Liu (2003). Biovolume was converted to biomass assuming $1 \mathrm{~mm}^{3}=1 \mathrm{mg}$ of fresh-weight biomass (Bingzhang and Liu, 2010). Phytoplankton $\mathrm{C}$ and $\mathrm{N}$ concentrations were calculated by applying the Menden-Deuer and Lessard equations (2000). Phytoplankton data were averaged for SUR and DEP at St. 1 and for the entire vertical profile at St. 2 at each sampling date. Weighted means were calculated for the photic zone ( $\mathrm{PZ}=2.5 \mathrm{SD})$.

Monthly rainfall values for the sampling period and those for the latest 6-year period (2006-2011), as recorded by the meteo-climatic station located close to the dam, were analyzed to evaluate the effects of rainfall trends.

Non-parametric tests for correlation and analysis of variance of the studied variables were applied using the program Statistica for Windows (StatSoft, 2001).

\section{Results}

\section{Environmental variables and nutrients}

Lake volume, and consequently water level, increased slowly from November to January and abruptly from
January to February because of heavy rainfall in the autumn-winter months (maximum of $180 \mathrm{~mm}$ in November; Fig. 2). The water level remained relatively stable until June. It decreased by about $5 \mathrm{~m}$ in July and the same trend continued until September, because of the low or absent rainfall in the summer months.

Rainfall was similar to that during 2006-2011; however, rainfall between autumn and spring was greater than the pluriannual average. As expected, wide seasonal variations were observed. SD transparency was lowest in February $(1.2 \mathrm{~m})$ and March $(1.5 \mathrm{~m})$, after the rainiest period and the consequent intense water input from the catchment (Fig. 3(a)). Water transparency gradually increased in spring, remaining stable at $c a .3 .5 \mathrm{~m}$ throughout summer.

Water temperature was homogeneous along the vertical profile, and was relatively low in winter $\left(5.5-7.3^{\circ} \mathrm{C}\right)$ when the lake was in a mixing condition (Figs. 3(a) and 4). Thermal stratification started in April, and lasted until September. The maximum temperature $\left(24.8^{\circ} \mathrm{C}\right)$ was recorded in SUR in July. The $\mathrm{pH}$ was around 7, with slightly higher values during the summer stratification in SUR. Simultaneously, lower $\mathrm{pH}$ values of around 6 were observed in DEP. During mixing, the values overlapped (Fig. 3(b)). DO varied accordingly, gradually declining towards the end of summer and the beginning of autumn, especially in DEP (Fig. 3(b)). DO values did not exceed $100 \%$ in SUR and were always higher than $38 \%$ in DEP.

Total nitrogen ranged between a minimum of $c a$. $600 \mathrm{mg} \mathrm{N} \cdot \mathrm{m}^{-3}$ in SUR (September) and a maximum of

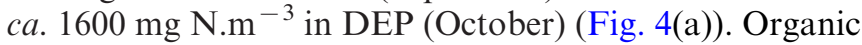
nitrogen contributed most to TN all year round. Nitrate was the main component of the DIN in both SUR and DEP samples (at least $75 \%$ ). During mixing time nitrate concentration was $c a .350 \mathrm{mg} \mathrm{N} . \mathrm{m}^{-3}$, while during the thermal stratification, nitrate concentration decreased in the epilimnion and increased slightly in the hypolimnion (Fig. 5). Total phosphorus ranged from $c a .20 \mathrm{mg} \mathrm{P.m}{ }^{-3}$ 


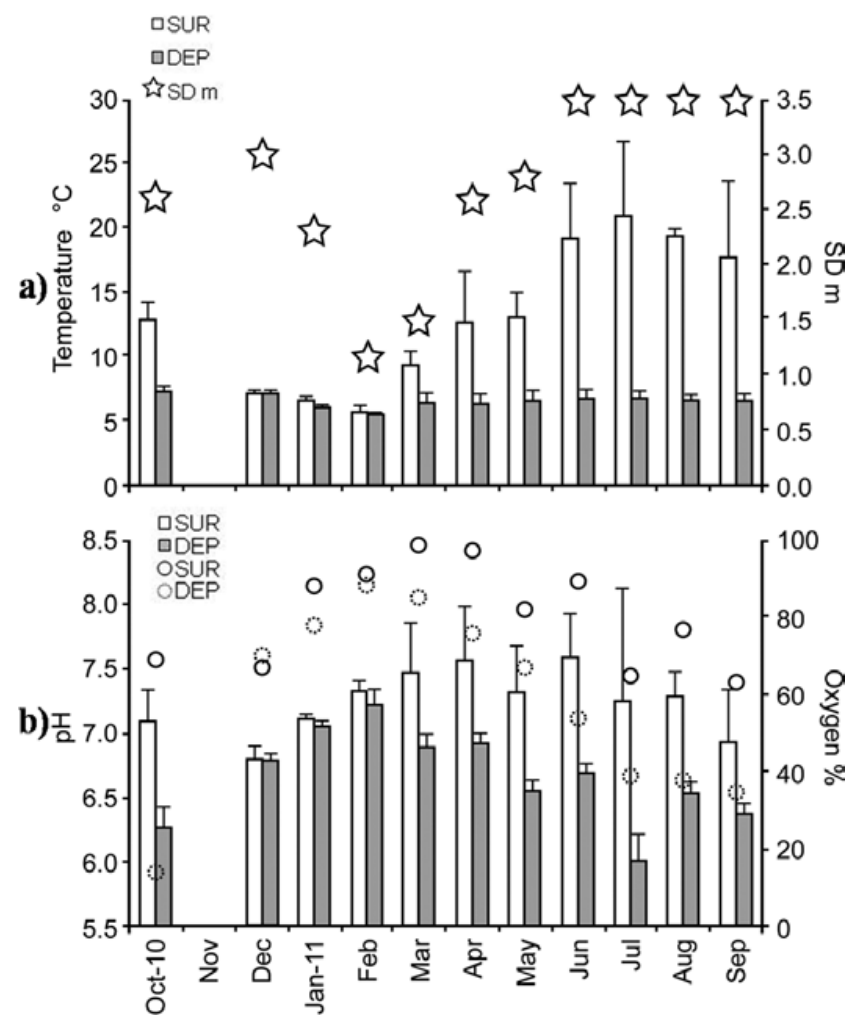

Fig. 3. (a) Temperature in SUR and DEP and SD (stars); (b) pH and oxygen (circles) dynamics at St. 1 in SUR and DEP.

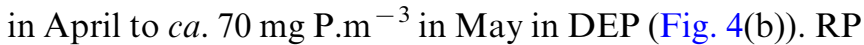
concentrations increased strongly in DEP from June to September during stratification, although RP concentration did not exceed $10 \mathrm{mg}$ P.m ${ }^{-3}$.

\section{Phytoplankton}

Chl $a$ concentration was always higher in SUR than in DEP, where it did not reach higher than $2 \mathrm{mg} \cdot \mathrm{m}^{-3}$ (Fig. 6(a)). Chl $a$ concentrations increased in SUR over the winter months from October, and reached maxima of $21.1 \mathrm{mg} \cdot \mathrm{m}^{-3}$ in February and $20.4 \mathrm{mg} \cdot \mathrm{m}^{-3}$ in March. During the same period, the extent of the PZ decreased, reaching minima of 2.9 and $3.8 \mathrm{~m}$ in February and March, respectively (Fig. 5(a)). Chl $a$ values were lowest in the spring months $\left(c a .7 \mathrm{mg} . \mathrm{m}^{-3}\right)$ and peaked again in summer $\left(c a .11 \mathrm{mg} \cdot \mathrm{m}^{-3}\right)$ when the PZ was at its highest $(8.8 \mathrm{~m}$ from June to September). Chl $a$ concentrations were highest in the upper layer during the colder months (Fig. 5). From April, the highest Chl $a$ concentrations were recorded below $2.5 \mathrm{~m}$ depth and, particularly from June to August, at $5 \mathrm{~m}$ depth.

Phytoplankton cell density and biomass were higher in SUR than in DEP, except during October (cell density) and December (cell density and biomass) when cell density and biomass were similar between the two layers (Fig. 6(b)). The cell density and biomass weighted mean values in the PZ overlapped with SUR values $\left(R^{2}=0.997\right.$
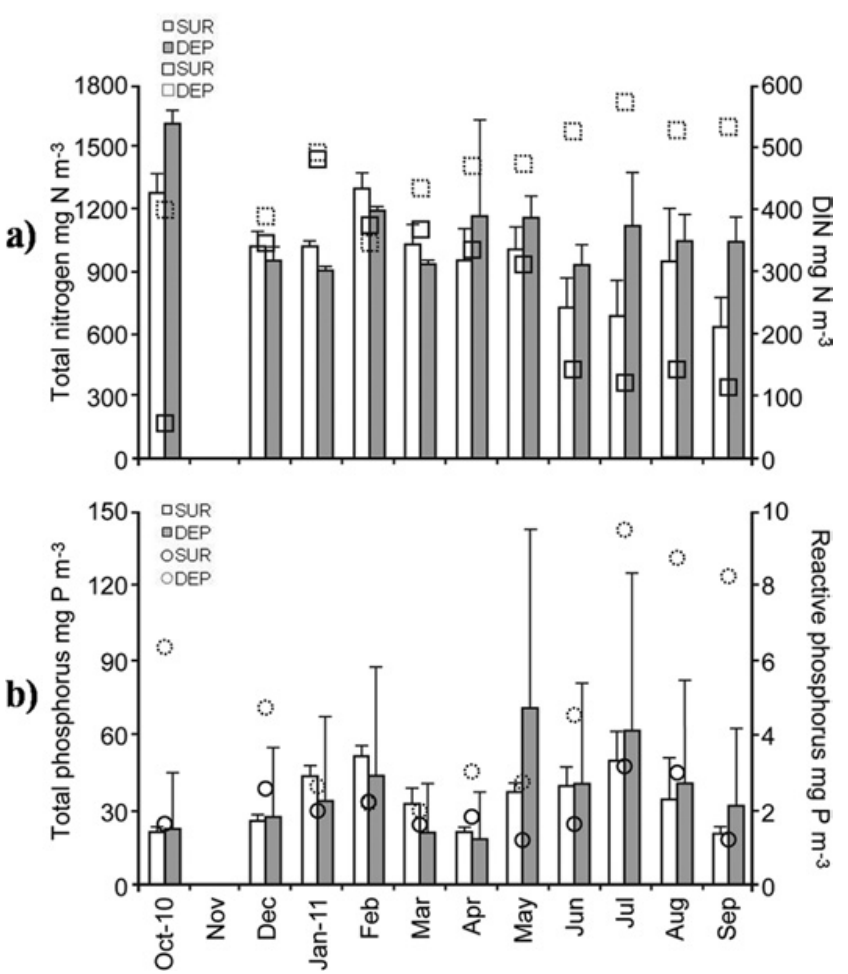

Fig. 4. (a) Dynamics for total nitrogen and DIN (squares); (b) total phosphorous and reactive phosphorus (circles) dynamics at St. 1 in SUR and DEP.

for density; $R^{2}=0.966$ for biomass; $n=11$ ), and ranged between $0.5 \times 10^{6}$ cells. $\mathrm{L}^{-1}$ in April and $14 \times 10^{6}$ cells. $\mathrm{L}^{-1}$ in September (density) and from $1.64 \mathrm{mg} . \mathrm{L}^{-1}$ in September to $32.74 \mathrm{mg} . \mathrm{L}^{-1}$ in March (biomass) (Fig. 6(b)).

Class composition of the phytoplankton cell density and biomass samples differed largely in all samples from both St. 1 and St. 2, and was much more diverse in the cell density samples than in the biomass samples. Cell density samples were dominated by Chlorophyceae (mainly Chlorella sp.) from October to December, Cryptophyceae (mainly Plagioselmis lacustris (Pascher and Ruttner) P. Javornick) and Dinophyceae (due to Gymnodinium uberrimum (G.J. Allman) Kofoid and Swezy) from January to May, and Cyanobacteria (mainly Aphanothece minutissima (W. West) KomárkováLegnerová and Cronbergmainly) in August and September, when cell density values were highest. In contrast, biomass samples were dominated by Dinophyceae (G. uberrimum). The vertical distribution of the naked dinoflagellate $G$. uberrimum along the water column showed a strong seasonal dynamic, with the species preferring shallow depths $(0-2.5 \mathrm{~m})$ during the winter and spring months, and the deepest epilimnetic depths (5-7.5 m) during the summer months (Fig. 5). Phytoplankton cell biomass, expressed as $\mathrm{C}$ and $\mathrm{N}$ content, was lower at St. 2 than in SUR samples at St. 1. The highest values were observed in the colder winter months from January to March, with annual peaks of 


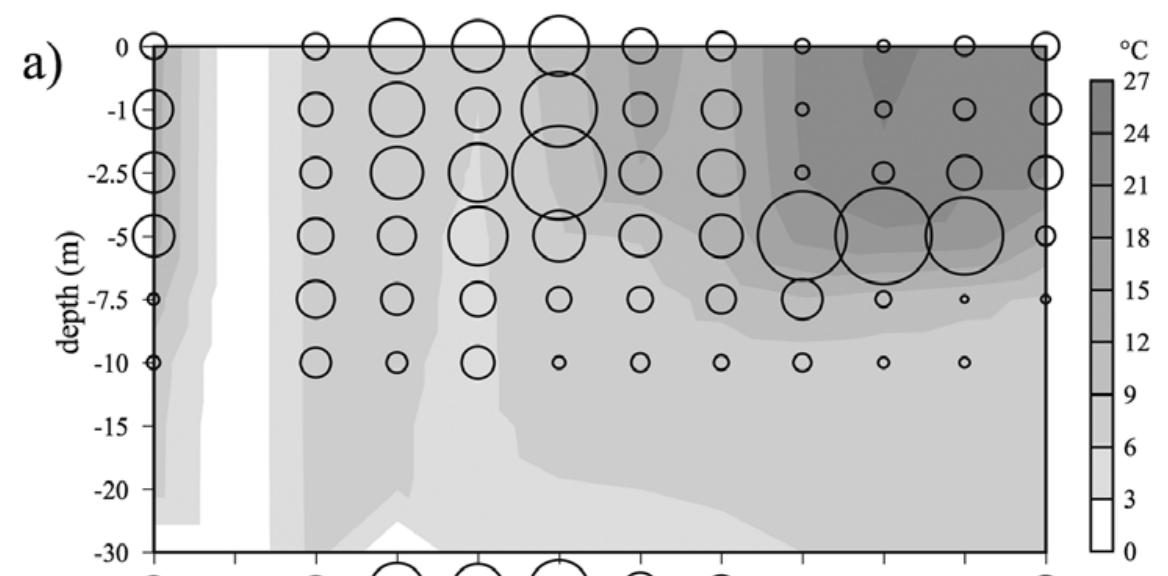

b)

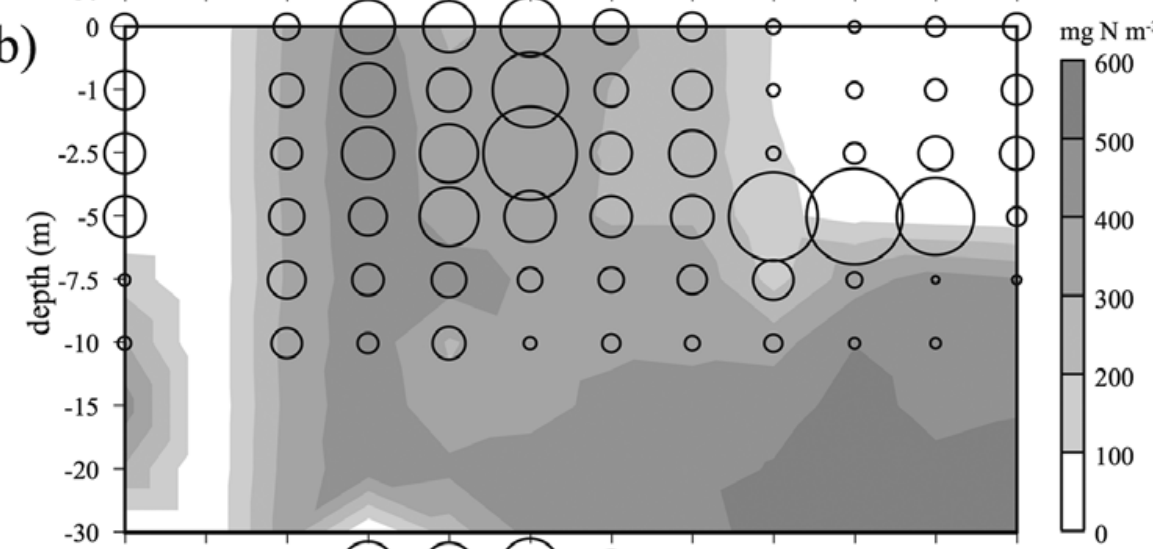

c)

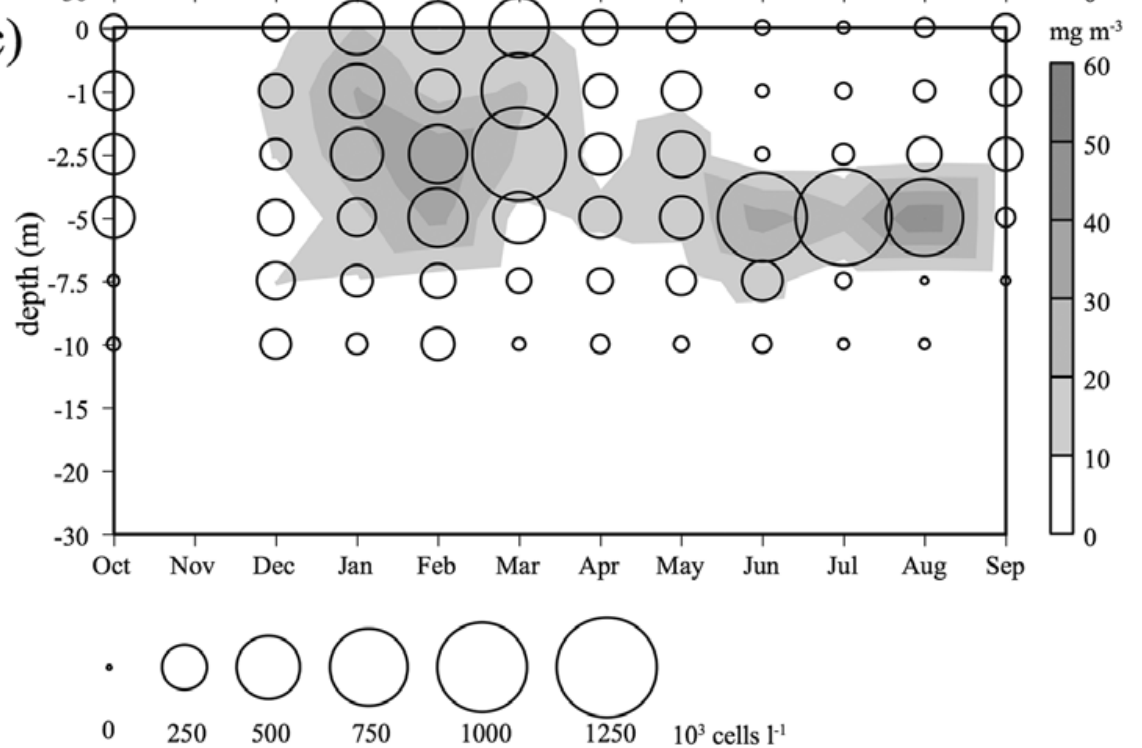

Fig. 5. Temporal and vertical dynamics of G. uberrimum with respect to temperature (a), nitrate (b) and chlorophyll $a$ (c) at St. 1 .

$5 \mathrm{mg} \mathrm{C.L} \mathrm{L}^{-1}$ and $3.8 \mathrm{mg} \mathrm{N} . \mathrm{L}^{-1}$. Cell biomass decreased after April when the water temperature increased.

\section{SPM and isotopic ratios}

At St. 1, SPM ranged from $1.74 \mu \mathrm{g}$ d.w.L $\mathrm{L}^{-1}$ in July to $5.25 \mu \mathrm{g}$ d.w. $\mathrm{L}^{-1}$ in March in SUR samples, and from $1.13 \mu \mathrm{g}$ d.w. $\mathrm{L}^{-1}$ in May to $5.42 \mu \mathrm{g}$ d.w. $\mathrm{L}^{-1}$ in February in DEP samples (Fig. 7(a)). At St. 2, SPM ranged from $1.93 \mu \mathrm{g} . \mathrm{L}^{-1}$ in June to $6.67 \mu \mathrm{g}$ d.w. $\mathrm{L}^{-1}$ in July, highlighting a different seasonal pattern between the stations. When the lake level was at its lowest, at the beginning and end of the study period (from October to January and in September), the amount of SPM in the SUR, DEP and St. 2 samples was similar. In February, when the lake level was at its maximum and mixing had occurred, SPM values increased at both St. 1 and St. 2. At St. 1, SPM values from 


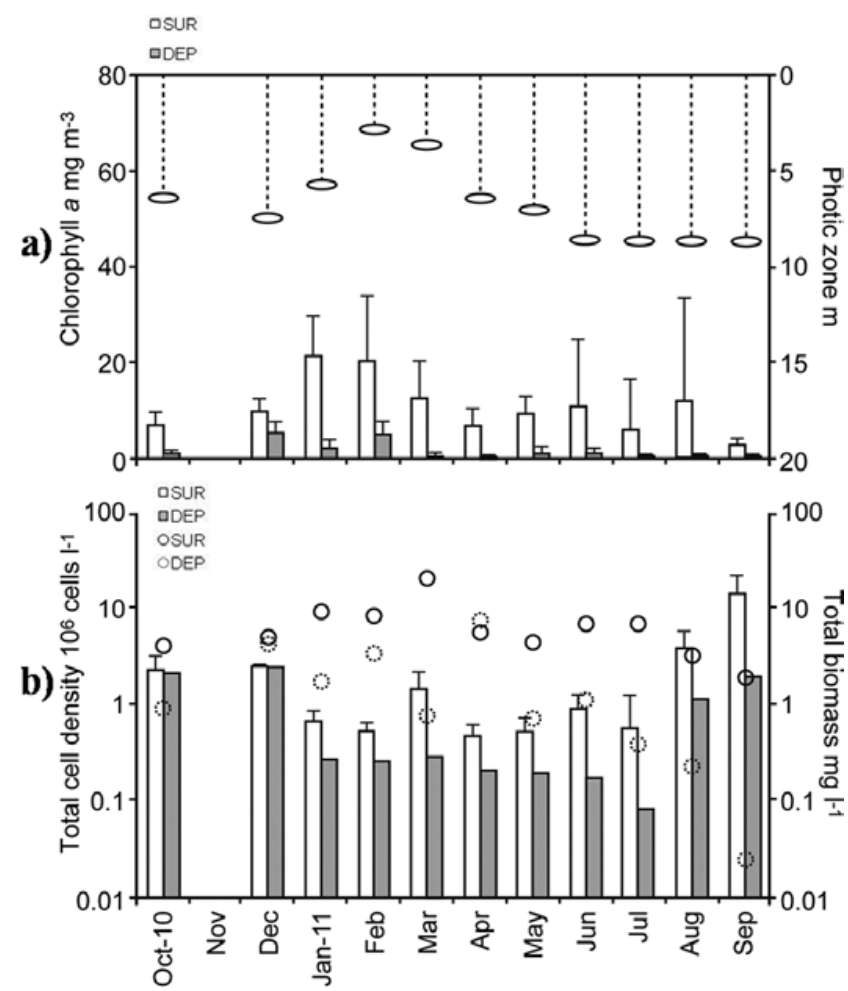

Fig. 6. a) Chlorophyll $a$ (column) and PZ (ovals); (b) total cell density (column) and phytoplankton biomass (circles) dynamics in SUR and DEP.

SUR and DEP samples overlapped and were twice those from the St. 2 samples. From March, the dynamics were more variable. There was a progressive decrease in SPM values in St. 2 samples, consistent with rainfall, until an unexpected and intense peak in July when the maximum SPM value was recorded. At St. 1, the SPM dynamics were less regular. Peak values were observed in the wet season (February and March), in concert with the maximum level of the lake, and at the same time as the maximum $\mathrm{Chl} a$ and of G. uberrimum cell densities in the upper depths (0-2.5 m; Fig. 6). In March, there was an abrupt decrease in SPM values in DEP samples, while SPM values were highest in SUR samples. In April, SPM values in SUR decreased to about the same level as those in DEP. In May and June, lower SPM values were observed in DEP samples than in SUR samples and in St. 2 samples.

The ranges of $\delta^{13} \mathrm{C}$ ratio values of SPM (Fig. 7(b)) were very similar in SUR and DEP samples at St. 1, varying from $-34.89 \%$ (December) to $-26.72 \%$ (May) in SUR, and $-35.26 \%$ (December) to $-26.48 \%$ (May-June) in DEP, and at St. 2, varying from $-35.42 \%$ (December) to $-26.28 \%$ o (June). The lowest values were measured in winter (December), and the highest values in summer (June and July). The $\delta^{13} \mathrm{C}$ ratio values fully overlapped at the beginning (from October to December) of the study period, and at the end (September) of the study period, during the autumn-winter months. The dynamics differed during the winter-spring months: values in SUR samples at St. 1 increased from December to February, and then
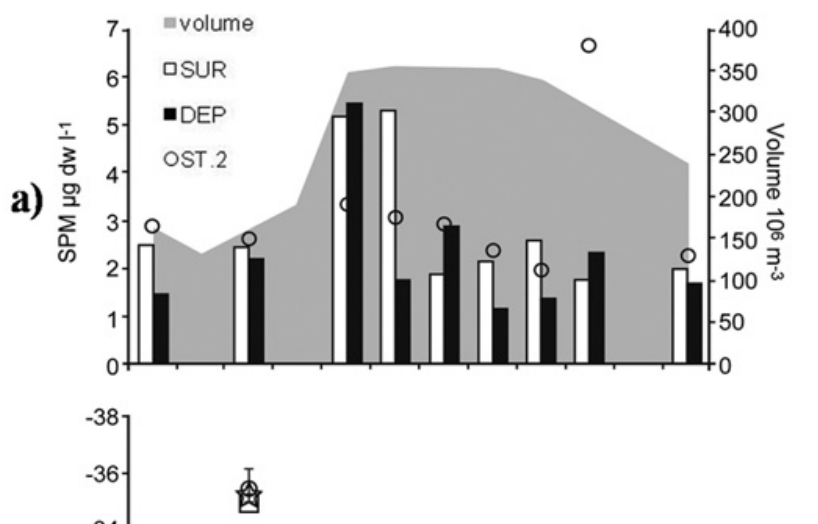

b)

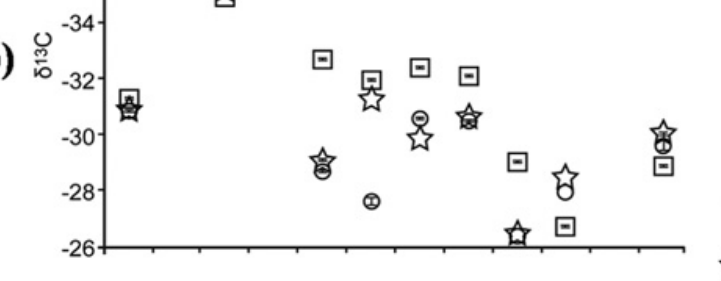

口SUR

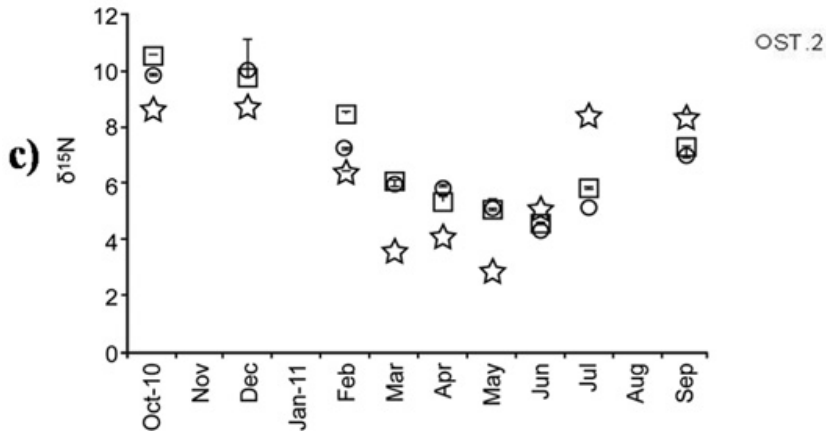

Fig. 7. (a) SPM dry-weight (columns and circles), monthly reservoir volume (gray area); (b) $\delta^{13} \mathrm{C}$ SPM isotopic ratio dynamics in SUR, DEP and St.2; (c) $\delta^{15} \mathrm{~N}$ SPM isotopic ratio dynamics in SUR, DEP and St.2.

remained quite constant until May, and were lower (i.e., more negative) than those in DEP samples at the same station and in St. 2 samples. The $\delta^{13} \mathrm{C}$ ratio values in DEP and St. 2 were very similar in February, April and May but not in SUR, while they differed in March when the values in DEP approached those in SUR. All the $\delta^{13} \mathrm{C}$ ratio values became higher $(-26 \pm 0.005 \%$ ) in June, and maintained remarkably different values in DEP and St. 2 samples compared with those in SUR. In July values further increased in SUR and became higher than they did in DEP and St. 2 samples. The mean ranks of the $\delta^{13} \mathrm{C}$ ratio values were significantly different between summer (June and July) and winter (December) (Kruskal-Wallis $H$ $(8, n: 54)=28.991, P=0.003)$. No significant differences in values were found among stations and different depth layers.

The $\delta^{15} \mathrm{~N}$ ratio values of SPM ranged from $4.56 \%$ (June) to $10.60 \%$ (October) in SUR, and from 2.97\%o (May) and 8.82\% (October-December) in DEP samples at St. 1, and from $4.37 \%$ (June) to $10.05 \% 0$ (December) at St. 2. Values were similar in October and December at ca. $10 \%$ (Fig. 7(c)), with a dynamic similar to that of the $\delta^{13} \mathrm{C}$ ratio values. The $\delta^{15} \mathrm{~N}$ ratio values sharply 
decreased, showing that there was low enrichment in DEP samples at St. 1 from February to May, and in SUR samples at St. 1 and St. 2 until June. In this period, $\delta^{15} \mathrm{~N}$ ratio values in DEP samples were lower (i.e., less enriched) than in SUR and St. 2 samples from October to May, becoming higher from June to September. $\delta^{15} \mathrm{~N}$ ratio values for SPM in samples from SUR at St. 1 and at St. 2 were very similar, and tended to decrease from December to June $(c a .4 \%)$, and then increased again from July to September. The mean ranks of the $\delta^{15} \mathrm{~N}$ ratio values showed a marked seasonality, and the values were significantly different between the spring (April, May and June) and autumn-winter months (October and December) (Kruskal-Wallis $H(8, n: 54)=40.273$, $P=0.002)$, with more $\mathrm{N}$ enrichment during the cooler months (Fig. 7(c)).

Oligochaetes collected from the sediments showed low $\delta^{13} \mathrm{C}$ ratios $(-34 \pm 0.19 \%)$, similar to the $\delta^{13} \mathrm{C}$ ratio values recorded in SPM in December, when the SUR, DEP and St. 2 values overlapped. $\delta^{13} \mathrm{C}$ ratio values for earthworms were higher $(-22.9 \pm 1.68 \%, n=10) . \delta^{15} \mathrm{~N}$ ratio values were $9.20 \pm 0.15(n=4)$ for terrestrial oligochaetes and $4.67 \pm 1.18(n=10)$ for earthworms, similar to the values at St. 1 (SUR) and St. 2 in autumn and June.

\section{Discussion}

\section{Hydrology, SPM and isotopic ratios}

SC was strongly affected by WLFs throughout the year (Fadda et al., 2014), with a clear seasonality as is generally reported for reservoirs in the Mediterranean area (Naselli-Flores, 2003; Geraldes and Boavida, 2005; Naselli-Flores and Barone, 2005). The lowest water level was reached in the autumn months (October and December) at the end of the driest period, and because of the constant year-round water withdrawal (Fig. 2) to produce drinkable water. The filling phase occurred in winter, and was mainly a result of rainfall via tributary inflows from the surrounding watershed. WLF is one of the most important stressors in lentic environments (Leira and Cantonati, 2008 and references therein), and has its greatest effects in shallow lakes and in the littoral zone. In thermally stratified lakes, WLF can cause unexpected water mixing, with strong effects on biota and ecosystem functioning (Naselli-Flores and Barone, 2005; Bond et al., 2008), including both top-down and bottom-up effects (Zohary and Ostrovsky, 2011). Rapid climate change affecting the planet is expected to further aggravate these effects, with larger WLF resulting from an increase in mean annual temperature, summer evaporation, modification of rainfall seasonal patterns, intensity and frequency of extreme rainfall events, and very long drought periods (Mulholland et al., 1997; Mooij et al., 2005; Barone et al., 2010). Compared with natural lakes, artificial lakes are more susceptible to these significant stress factors (Naselli-Flores, 2003).
Moreover, the unpredictable climate variability and prolongation of drought in the Mediterranean basin often cause complete drying of the upland tributaries, as is virtually the case in the upper stream of River Tirso. In the dry season (early summer-early autumn), a large amount of plant detritus can accumulate on the dry riverbed, which can be transported into the reservoir after the first rainfall at the end of summer and beginning of autumn. Consequently, we hypothesize that there was input of external material from the watershed, which results in ratios for nutrients that are close to those of the terrestrial origin, and indicates more enrichment in ${ }^{13} \mathrm{C}$, as is expected in the lake (Finlay and Kendall, 2008).

In the case of SC, during the filling phase in February (WLF of $+10 \mathrm{~m}$ greater than in December) transparency decreased, reaching a minimum of $1.2 \mathrm{~m} \mathrm{SD}$, and SPM increased. Simultaneously, $\delta^{13} \mathrm{C}$ ratio values were less negative than in autumn. In this season, in SUR and DEP samples at St. 1 and samples at St. $2, \delta^{13} \mathrm{C}$ and $\delta^{15} \mathrm{~N}$ ratio values overlapped, respectively. In particular, in February, the $\delta{ }^{13} \mathrm{C}$ ratio value for SUR was lower than the DEP and St. 2 values, and similar to those recorded in previous months, indicating the presence of SPM of autochthonous origin. In contrast, the $\delta^{13} \mathrm{C}$ ratio value for DEP overlapped with that for St. 2, indicating tracing of the water inflow from the watershed into the reservoir. Because inflow water density usually differs from that of the water already present in a reservoir (e.g., due to temperature, total dissolved solid and SPM), inflows enter and move through reservoirs as a density current (Ford, 1990 and references therein).

The $\delta^{13} \mathrm{C}$ ratio value for bottom-benthic oligochaetes $(-34 \pm 0.24 \%$ ) collected from the sediments of SC was closer to the values for SUR than those for DEP or St. 2 during the filling phase, which supports the hypothesis mentioned above. The SPM origins during the filling phase, as traced by $\delta^{13} \mathrm{C}$ ratio analysis, were also supported by the lower $\delta^{15} \mathrm{~N}$ ratio values during the same phase, especially when the DEP $\delta^{15} \mathrm{~N}$ ratio values at St. 1 were close to that for earthworms $(4.67 \pm 1.18, n=10)$. In fact, ratio values for material of terrestrial origin generally indicate less enrichment than those for material of aquatic origin (Finlay and Kendall, 2008). Overall, the $\delta^{15} \mathrm{~N}$ ratio values were negatively correlated with lake water levels (Spearman's rank $R=-0.72 ; n=54$; $P=0.0001)$.

\section{Environmental conditions, SPM and isotopic ratios}

More so than hydrological variability, physical variables such as temperature are important determinants of $\delta^{13} \mathrm{C}$ seasonal changes (Rau et al., 1989). The results from the study confirmed the warm-monomictic seasonal thermal dynamic of SC with depleted $\delta^{13} \mathrm{C}$ and enriched $\delta^{15} \mathrm{~N}$ in winter (cooler months) and more enriched $\delta^{13} \mathrm{C}$ and depleted $\delta^{15} \mathrm{~N}$ in summer (warmer months). In monomictic lakes, a positive correlation between $\delta^{13} \mathrm{C}$ and temperature is often observed (Zohary et al., 1994; Perga 
and Gerdeaux, 2006; Caroni et al., 2012). When temperature increases, atmospheric dissolution decreases; hence, changes in internal $\mathrm{CO}_{2}$ sources can lead to a positive correlation between $\mathrm{CO}_{2}$ and temperature. Temperature controls the solubility of $\mathrm{CO}_{2}$ and in turn influences the fractionation of $\mathrm{C}$ isotopes during phytoplankton uptake (Rau et al., 1989, 1992). In our study, $\delta^{13} \mathrm{C}$ ratios of SPM increased (i.e., to less negative values) from May to July, when the reservoir was thermally stratified and surface temperature reached a maximum. A positive correlation was only found between SUR $\delta^{13} \mathrm{C}$ ratio and temperature (Spearman's rank $R=0.883 ; n=9$; $P=0.007$ ). A different uptake of dissolved inorganic carbon by phytoplankton may have been responsible for this relationship.

In stratified lakes and reservoirs, biological activities affect the hypolimnetic waters, decreasing the dissolved oxygen, $\mathrm{pH}$ and redox potential at the water-sediment interface (Nowlin et al., 2005). Moreover, prolongation of the dry season, and stagnation of waters and a consequent lower redox potential, can enhance the remobilization of nutrients from the sediments (Boström et al., 1988; Zohary et al., 1994). In SC, at St. 1, pH and oxygen reduction occurred in the DEP in summer, even though anoxia was not observed. Consequently, nitrification processes may have occurred, contributing to the increase of DIN in DEP samples in summer months (in June and especially in July). Indeed, $\delta^{15} \mathrm{~N}$ ratio values of DEP samples may have reflected degradation processes. In contrast, from April to June, the DIN decrement in SUR samples may have been due to phytoplankton uptake, which is consistent with the corresponding decrease in the $\delta^{15} \mathrm{~N}$ ratio.

A conceptual model developed for the Great Lakes (USA) states that the $\delta^{15} \mathrm{~N}$ of seston is controlled by the balance between $\mathrm{NH}_{4}^{+}$uptake and degradation processes, which increase $\delta^{15} \mathrm{~N}$, and $\mathrm{NO}_{3}^{-}$uptake and decreases the $\delta^{15} \mathrm{~N}$ of seston (McCusker et al., 1999). Furthermore, in SC, phosphorous tended to increase in DEP samples at St. 1 during stratification and when external inputs were negligible, suggesting the importance of internal recycling in deeper waters.

Further, with regard to the $\mathrm{C}$ ratios, hypolimnetic intense respiratory activity can lead to a decrease in isotopic ratios: organisms that rely on deep water sources, where respiration activity is increased, have lower (i.e., more negative) $\mathrm{C}$ ratios than those living closer to the surface and/or littoral zone (Vander Zanden and Rasmussen, 1999; Grey, 2000; Cattaneo et al., 2004).

\section{Phytoplankton, SPM and isotopic ratios}

In the SUR samples at St. 1, an important contribution by phytoplankton of surface SPM was indicated by significant correlations between SPM weight and Chl $a$ (Spearman's rank $R=0.883 ; n=9 ; P=0.001$ ) and total phytoplankton biomass (Spearman's rank $R=0.636$; $n=11 ; P=0.03)$. Correlations were not found significant between phytoplankton and SPM weight in DEP samples at St. 1 and St. 2 samples, whose dynamics may have been mainly related to physical and chemical processes, as described above. On this basis, the following discussion focuses on data relative to SUR, i.e., the surface layer $(0-7.5 \mathrm{~m})$ at the lacustrine station (St. 1).

Phytoplankton biomass was mainly composed of G. uberrimum (Spearman's rank $R=0.636 ; n=11$; $P=0.03$ ), which is a mixotrophic naked dinoflagellate. In $\mathrm{SC}$, there were more favorable conditions for this species in the upper depths $(-2.5 \mathrm{~m})$ in the colder winter months (from December to March) when the lake was in a mixing condition, and in the deeper layers $(-5 \mathrm{~m})$ in the warmer summer months (June and July) when the lake was stratified. G. uberrimum is able to move up and down the water column daily (Tilzer, 1973; Queimaliños et al., 2002; Niesel et al., 2007), and has seasonal preferences for specific water layers (Niesel et al., 2007 and references therein). Although stratified conditions are thought to help motile species, recent studies report a high competitiveness of G. uberrimum in mixed water, when the motile cells cannot use their ability to move (Niesel et al., 2007). Moreover, a positive phototaxis was reported for G. uberrimum in a high altitude lake, whereas a negative phototaxis was reported in a mid-range altitude lake (Rott, 1981). In SC, during winter when the $\mathrm{PZ}$ was lower, G. uberrimum was mainly recorded in the upper water layer $(-2.5 \mathrm{~m})$, whereas when the PZ increased, it swam into the epilimnetic deeper layers.

G. uberrimum is regarded as an oligo- to mesotrophic species, which benefits from low phosphorus concentrations (Tilzer, 1973; Niesel et al., 2007). In SC, an association between G. uberrimum seasonal distribution and the concentration of nitrate along the water column was observed, as has been reported for other gymnodiales (Cullen and Horrigan, 1981). When SC was thermally stratified, $\mathrm{NO}_{3}^{-}$tended to decrease in the epilimnetic layers with a decrease in $\delta^{15} \mathrm{~N}$, as discussed above. In September, when the G. uberrimum population decreased, the concentration of nitrate in the epilimnion was strongly reduced. Moreover, N-dinoflagellate biomass content was strongly correlated with nitrate (Spearman's rank $R=0.7$; $n=11 ; P=0.001)$.

Though G. uberrimum is believed to indicate good water quality (Marchetto et al., 2009), it is not widely reported in Sardinia or in other Mediterranean artificial lakes. In-depth studies on the ecology of this species may help to better understand its functional role in artificial lakes in the Mediterranean basin.

\section{Conclusions}

Lake SC is a small warm monomictic reservoir where annual hydrological cycles affect the $\mathrm{C}$ and $\mathrm{N}$ ratios of SPM. Being a Mediterranean reservoir, SC is characterized by different phases: one of stagnant low-water levels from late summer to the beginning of winter, and the 
others, being more dynamic, from winter to spring during re-filling and at stable high water levels (until early summer). SPM quantity and composition were influenced by these annual dynamics. The hydrological dynamics, as shown by WLFs, led to a seasonality in $\delta^{15} \mathrm{~N}$ ratios associated with phytoplankton growth and internal recycling, whereas $\delta^{13} \mathrm{C}$ ratios allowed tracing of the water (and material) inflow from the watershed into the reservoir. Further, isotopic ratios of SPM were influenced by phytoplankton composition and its uptake activity (Zohary et al., 1994; Lehman et al., 2004; Gu et al., 2006).

An apparent anomalous $\delta^{13} \mathrm{C}$ ratio distribution along the water column during the filling phase, which partially retained the ratios of previous months, suggests a peculiar behavior of phytoplankton in the lake. The biomass of the phytoplankton community and surface water SPM was dominated by G. uberrimum, which found advantageous conditions in the mixed water during winter, when it preferred the surface layers. On the contrary, during summer thermal stratification, the species moved to deeper water layers, as has been reported in other environments (Tilzer, 1973; Queimaliños et al., 2002; Niesel et al., 2007).

Our study confirms the high level of ecological complexity of artificial lakes, and shows that SIA is a useful tool for interpreting the dynamics of hydrologic and biotic processes within these ecosystems.

Acknowledgements. I thank my family for the support. A special thank to S. Cadelano, M. Vascellari, O. Soru, B. Begliutti and L. Dessi.

\section{References}

Barone R., Castelli G. and Naselli-Flores L., 2010. Red sky at night cyanobacteria delight: the role of climate in structuring phytoplankton assemblage in a shallow, Mediterranean lake (Biviere di Gela, southeastern Sicily). Hydrobiologia, 639, 43-53.

Bingzhang C. and Liu H., 2010. Relationships between phytoplankton growth and cell size in surface oceans: interactive effects of temperature, nutrients and grazing. Limnol. Oceanogr., 55, 965-972.

Bond N.R., Lake P.S. and Arthington A.H., 2008. The impacts of drought on freshwater ecosystems: an Australian perspective. Hydrobiologia, 600, 3-6.

Boström B., Andersen J., Fleischer S. and Jansson M., 1988. Exchange of phosphorus across the sediment-water interface. Hydrobiologia, 170, 229-244.

Camin F., Moschella A., Miselli F., Parisi B., Versini G., Ranalli P. and Bagnaresi P., 2007. Evaluation of markers for the traceability of potato tubers grown in organic vs conventional regime. J. Food Sci. Agric., 87, 1330-1336.

Caroni R., Free G., Visconti A. and Manca M., 2012. Phytoplankton functional traits and seston stable isotopes ratio: a functional-based approach in a deep, subalpine lake, Lake Maggiore (N. Italy). J. Limnol., 71, 84-94.
Cattaneo A., Manca M. and Rasmussen J.B., 2004. Peculiarities in the stable isotope composition of organisms from an alpine lake. Aquat. Sci., 66, 440-445.

Cullen J.J. and Horrigan S.G., 1981. Effects of nitrate on the diurnal vertical migration, carbon to nitrogen ratio, and the photosynthetic capacity of the dinoflagellate Gymnodinium splendens. Mar. Biol., 62, 81-89.

Fadda A., Marková S., Kotlík P., Lugliè A., Padedda B., Sechi N. and Manca M., 2011. First record of planktonic crustaceans in Sardinian reservoirs. Biologia, 66, 856-865.

Fadda A., Rawcliffe R., Padedda B.M., Luglie A., Sechi N., Camin F. and Manca M., 2014. Spatiotemporal dynamics of $\mathrm{C}$ and $\mathrm{N}$ isotopic signature of zooplankton: a seasonal study on a man-made lake in the Mediterranean region. Ann. Limnol. Int. J. Lim., 50, 279-287.

Finlay J.C. and Kendall C., 2008. Stable isotope tracing of temporal and spatial variability in organic matter sources to freshwater ecosystems. In: Michener R. and Lajtha, K. (eds.), Stable Isotopes in Ecology and Environmental Science (2nd edn), Blackwell Publishing Ltd, Victoria, Australia, p. 283-324.

Ford D.T., 1990. Reservoir storage reallocation analysis with PC. J. Water Resour. Plan. Manage., 116, 402-416.

Fresenius W.K.E., Quentin W.W. and Scheneider W., 1988. Water Analysis. A Practical Guide to Physico-Chemical and Microbiological Water Examination and Quality Assurance, Springer-Verlag, Berlin.

Geraldes A.M. and Boavida M.J., 2005. Seasonal water level fluctuations: implications for reservoir limnology and management. Lake Reserv. Manage., 10, 59-69.

Goltermann H.L., Clymo R.S. and Ohnstad M.A.M., 1978. Method for Physical and Chemical Analysis of Fresh Waters, IBP Manual, No. 8, Blackwell Scientific, Oxford.

Grey J., 2000. Trophic fractionation and the effects of diet switch on the carbon stable isotopic "ratios" of pelagic consumers. Verh. Int. Verein. Limnol., 27, 3187-3191.

Grey J., 2006. The use of stable isotope analyses in freshwater ecology: current awareness. Pol. J. Ecol., 54, 563-584.

Grey J. and Jones R.I., 2001. Seasonal changes in the importance of the source of organic matter to the diet of zooplankton in Loch Ness, as indicated by stable isotope analysis. Limnol. Oceanogr., 46, 505-513.

$\mathrm{Gu}$ B., Chapman A.D. and Schelske C.L., 2006. Factors controlling seasonal variations in stable isotope composition of particulate organic matter in a soft water eutrophic lake. Limnol. Oceanogr., 51, 2837-2848.

Huber-Pestalozzi G., 1938-1983. Das phytoplankton des Süßwassers, Schweizerbart'sche Verlagsbuchhandlung (Nägele u. Obermiller), Stuttgard.

Hustedt F. (ed.). 1985. The Pennate Diatoms, Koeltz Scientific Books, Königstein.

Jeppesen E., Jensen J.P., Søndegard M. and Lauridsen T., 1999. Trophic dynamics in turbid and Clearwater lakes with special emphasis on the role of zooplankton for water clarity. Hydrobiologia, 408/409, 217-231.

Komárek J. and Anagnostidis K., 1999, 2005. Süßwasserflora von Mitteleuropa, Cyanoprokaryota, Gustav Fischer, JenaStuttgart-Lübeck-Ulm. 
Krammer K. and Lange-Bertalot H., 1986-1991. Süßwasserfloravon Mitteleuropa. Bacillariophyceae. 2/1: Naviculaceae, 1986,876 p. 2/2 Bacillariaceae, Epithemiaceae, Surirellaceae, 1988, 596 p; 2/3: Centrales, Fragilariaceae, Eunotiaceae, 1991, 576 p; 2/4 Achnantaceae, 1991, 437 p. Gustav Fisher verlag, Stuttgard.

Lehman M.F., Bernasconi S.M. and McKenzie J.A., 2004. Seasonal variation of the $\delta^{13} \mathrm{C}$ and $\delta^{15} \mathrm{~N}$ of particulate and dissolved carbon and nitrogen in Lake Lugano: constraints on biogeochemical cycling in a eutrophic lake. Limnol. Oceanogr., 49, 415-429.

Leira M. and Cantonati M., 2008. Effects of water-level fluctuations on lakes: an annotated bibliography. Hydrobiologia, 612, 171-184.

Luglié A., Mameli G. and Sechi N., 1996. Indagine limnologica pluriennale (dal 1991 al 1993) sul lago artificiale di Sos Canales (Sardegna Settentrionale). Atti dell'11 ${ }^{\circ}$ Congresso A.I.O.L. - Sorrento, 26-28 October 1994, 479-489.

Marchetto A., Padedda B.M., Mariani M.A., Lugliè A. and Sechi N., 2009. A numerical index for evaluating phytoplankton response to changes in nutrient level deep mediterranean reservoirs. J. Limnol., 68, 106-121.

McCusker E.M., Ostrom P.H., Ostrom N.E., Jeremiason J.D. and Baker J.E., 1999. Seasonal variation in the biogeochemical cycling of seston in Grand Traverse Bay, Lake Michigan. Org. Geochem., 30, 1543-1557.

Menden-Deuer S. and Lessard E.J., 2000. Carbon to volume relationships for dinoflagellates, diatoms, and other protist plankton. Limnol. Oceanogr., 45, 569-579.

Mooij W.M., Hülsman L.N., De Senerpont Dmis B.A., Nolet P.L.E., Bodelier P.C.M., Dionisio Pires H.J., Gons B.W., Ibelings R., Noordhuis R., Portielje K. and Wolfstein Lammens E.H.R.R., 2005. The impacts of climate change on lakes in the Neetherlands: a review. Aquat. Ecol., 39, 381-400.

Mulholland P.J., Marzolf E.R., Webster J.R., Hart D.R. and Hendricks S.P., 1997. Evidence that hyporheic zones increase heterotrophic metabolism and phosphorus uptake in forest streams. Limnol. Oceanogr., 42, 443-451.

Naselli-Flores L., 2003. Man-made lakes in Mediterranean semi-arid climate: the strange case of Dr Deep Lake and Mr Shallow Lake. Hydrobiologia, 506, 13-21.

Naselli-Flores L. and Barone R., 2005. Water-level fluctuations in Mediterranean reservoirs:setting a deatering threshold as a management tool to improve water quality. Hydrobiologia, 548, 85-95.

Niesel V., Hehn E., Sudbrack R., Willmitzer H. and Chorus I., 2007. The occurrence of the Dynophyte species Gymnodinium uberrimum and PeridiniumWillei in German reservoirs. J. Plankt. Res., 29, 347-357.

Nowlin W., Evarts J.L. and Vanni J., 2005. Release rates and potential fates of nitrogen and phosphorous from sediments in a eutrophic reservoir. Freshwat. Biol., 50, 301-322.

Perga M.E. and Gerdeaux D., 2006. Seasonal variability in the $\delta^{13} \mathrm{C}$ and $\delta^{15} \mathrm{~N}$ values of the zooplankton taxa in two alpine lakes. Acta Oecol., 30, 69-77.

Queimaliños C., Perez G. and Modenutti B., 2002. Summer population development and diurnal vertical distribution of dinoflagellates in an ultraoligotrophic Andean lake (Patagonia, Argentina). Algologic. Stud., 107, $117-129$.

Rau G.H., Takahashi T. and des Marais D.J., 1989. Latitudinal variations in plankton ${ }^{13} \mathrm{C}$ : implications for $\mathrm{CO}_{2}$ and productivity in past oceans. Nature, 341, 516-518.

Rau G.H., Takahashi T., des Marais D.J., Repeta D.J. and Martin J.H., 1992. The relationship between ${ }^{13} \mathrm{C}$ of organic matter and $\left[\mathrm{CO}_{2}\right.$ (aq)] in ocean surface water: data from a JGOFS site in the northeast Atlantic Ocean and a model. Geochim. Cosmochim. Acta, 56, 1413-1419.

Rott E., 1981. Some results from phytoplankton counting intercalibrations. Schweiz. Z. Hydrol., 43, 34-63.

Sechi N. and Lugliè A., 1992. Limnological studies on man-made lakes in Sardinia (Italy). Mem. Ist. Ital. Idrobiol., 50, 365-381.

Sechi N. and Luglié A., 1996. Phytoplankton in Sardinian reservoirs. Gior. Bot. Ital., 130, 977-994.

StatSoft Inc., 2001. STATISTICA for Windows (Data Analysis Software System), Version 6, StatSoft, Tulsa, 1098 p.

Straškraba M. and Tundisi J.G., 1999. Reservoir Water Quality Management. Guidelines of Lake Management, Vol. 9, International Lake Environment Committee, Kusatsu.

Strickland J.D.H. and Parsons T.R., 1972. A practical handbook of water analysis. J. Fish. Res. Bd. Can.

Suda S., Watanabe M.M., Otsuka M.M., Mahakant A., Yongmanitchai W. and Nopartnaroporn N., 2002. Taxonomic revision of water-bloom-forming species of oscillatoriod cyanobacteria. Int. J. Syst. Evol. Micrbiol., 52, $1577-1595$.

Sulzman E., 2008. Stable isotope chemistry and measurement: a primer. In: Michener R. and Lajtha K. (eds.), Stable isotopes in ecology and environmental science, (2nd edn), Blackwell Publishing Ltd, Victoria, Australia, pp. 1-18.

Sun J and Liu D., 2003. Geometric models for calculating cell biovolume and surface area for phytoplankton. J. Plankton Res., 25, 1331-1346.

Teranes J. and Bernasconi S.M., 1999. The record of nitrate utilization and productivity imitation provided by $\delta^{15} \mathrm{~N}$ values in lake organic matter - a study of sediment trap and core sediments from Baleggersee, Switzerland. Limnol. Oceanogr., 45, 801-813.

Tilzer M.M., 1973. Diurnal periodicity in the phytoplankton assemblage of a high mountain lake. Limnol. Oceanogr., 18, $15-30$.

Tundisi G. and Matzumura-Tundisi J., 2003. Integration of research and management in optimizing multiple uses of reservoirs: the experience in South America and Brazilian case studies. Hydrobiologia, 500, 231-242.

Utermhöl H., 1958. Zur vervollkhung der quantitativen phytoplanktonmethodik. Mitt. Int. Verein. Limnol., 9, $1-38$.

Vander Zanden M.J. and Rasmussen J.B., 1999. Primary consumer ${ }^{13} \mathrm{C}$ and ${ }^{15} \mathrm{~N}$ and the trophic position of aquatic consumers. Ecology, 80, 1395-1404.

Visconti A., Volta P., Fadda A., Di Guardo A. and Manca M. 2013a. Seasonality, littoral versus pelagic carbon sources, 
and stepwise $15 \mathrm{~N}$-enrichment of pelagic food web in a deep subalpine lake: the role of planktivorous fish. Can. J. Fish. Aquat. Sci. 71, 436-446.

Visconti A., Volta P., Fadda A. and Manca M. 2013b. Roach in lake Maggiore: a peaceful invasion detected with C, N stable isotope analysis. Glob. J. Sci. Front. Res. D, 13, $1-8$.
Zohary T. and Ostrovsky I., 2011. Ecological impacts of excessive water level fluctuations in stratified freshwater lakes. Inland Water, 1, 47-59.

Zohary T., Erez J., Gophen M., Bermanfrank I. and Stiller M., 1994. Seasonality of stable carbon isotopes within the pelagic food web of Lake Kinneret. Limnol. Oceanogr., 39, 1030-1043. 